\title{
The Influence of Learning Motivation, Learning Ways, and Variation of Teaching Styles Towards Learning Activeness in the Subject of Public Administration at Grade X Students of Automatic Expertise Program and Office Governance of Vocational High School $\mathrm{NU} 01$ Kendal in the Academic Year of 2017/2018
}

\section{Sapuroh, Nanik Suryani, Fahrur Rozi, and Nindya Purnama}

The Faculty of Economics Universitas Negeri Semarang

\section{Abstract}

Corresponding Author:

Sapuroh

Sapuroh49@gmail.com

Received: 7 August 2018

Accepted: 15 September 2018

Published: 22 October 2018

Publishing services provided by Knowledge E

(c) Sapuroh et al. This article is distributed under the terms of the Creative Commons

Attribution License, which permits unrestricted use and redistribution provided that the original author and source are credited.

Selection and Peer-review under the responsibility of the ICE-BEES 2018 Conference Committee.
The purpose of this study was to know whether or not learning motivation, learning ways, and variation of teaching styles influence students learning activeness simultaneosly and partially.The population of this study was 80 Grade X Students of Automatic Expertise Program and Office Governance of Vocational High School $\mathrm{NU} 01$ Kendal. Sampling technique used saturated sampling that is all members of the population become the sample of the study. The data were obtained through questionnaire, observation, interview, and documentation. The data were analyzed by using classis assumption test analysis, multiple regression analysis, hypothesis test analysis, percentage descriptive analysis using SPSS for Windows Release 23.The findings of this study shows that multiple regression analysis obtained equation: $\mathrm{Y}=$ $3.304+0,406 x_{1}+0.221 x_{2}+0.170 x_{3}+$ e. Simultaneosly, Learning motivation, learning ways, variation of teaching style influence students learning activeness positively and significantly in the amount of 56.1percent. While partially, learning motivation influences students learning activeness in the amout of 16,81percent, learning ways 7.29percent, and variation of teaching style 7.56percent. It can be concluded that learning motivation, learning ways, variation of teaching styles influence students learning activeness simultaneosly and partially.

Keywords: Learning Motivation, Learning Ways,Variation of Teaching Styles, and Students Learning Activeness.

\section{S OPEN ACCESS}




\section{Introduction}

Education is basically aimed at delivering students toward behavior change such as intellectual, moral, and social. UU No. 20 the Year 2003 explains that education is a conscious and planned effort to create the learning atmosphere and process in order that students develop actively their potential to have spiritual power, self-control, personality, intelligence, noble character, and also skills needed by him, his society, and his country [22]. Tusyanah et al. (2016) explained that "Indonesia Government always strives to improve education qualities such as improving school facilities, improving teacher competence, and changing the curriculum" [21].

Ratnawati (2014) explained that "Education is an effort to make changes in attitudes and behaviors of a person through the learning process so that students are active to develop the potential that he has [14]. Yulianto (2007) explained that "Learning requires active participation between teachers and students, and the carrying capacity of learning through the use of media and learning resources. Therefore, the role of teachers in improving students' learning motivation determines the level of students' learning success" [25]. Based on those opinions, it is expected that education remains a concern and orientation to improve the education quality to be better. With the good education quality then students can achieve the expected goals when following the learning process. The learning process, of course, requires an active role between students and teachers, as well as the components exist in schools.

The purpose of education is to educate the nation's life, and a good education is expected to improve one's knowledge and skills. The purpose of education can be achieved one of them by learning. Rifa'l \& Catharina (2012: 82) argued that "Learning plays an important role in the development, habits, attitudes, beliefs, goals, personality, and even one's perception" [15]. Through learning the student can develop himself into a better person and enable to make changes in knowledge, attitude, and skills. Changes that occur in individuals depend on the process of learning activities undertaken by students. The learning process will be maximized if the teacher in explaining the subject matter can be easily understood by the students.

Student learning activity is an important factor in the learning process. Sudjana (2010: 20) stated that "Student learning activity is a process of teaching and learning activities that subjects intellectually and emotionally involved so that they play an active role and participate in learning activities" [18]. According to Dimyati \& Mudjiono (2006: 114) "Every learning process must show the activity of people who study or students" [3]. Therefore, students in following the learning process should actively 
ask questions and submit opinions. In addition, Widiati (2016) stated that "Student activity in the learning process is an effort by students to gain learning experience" [24]. According to Susilowati (2016) "Activity learning is very important in the learning process. It is said to be important because students show a wide range of activities. An activity of learning will facilitate the teacher to know how far ability obtained by the student during learning process" [22].

Learning motivation is one of the factors that allegedly can affect the activeness learning in the classroom. Learning motivation is needed in the process of teaching and learning because with a high motivation it will make students active in the learning process and understand the material described by the teacher. Donald in Sadirman (2007: 73) explained that "Motivation is a change of energy in a person characterized by the emergence of feeling and preceded by a response to the purpose" [16]. According to Dimyati \& Mudjiono (2006: 80) explained that "Motivation is seen as a mental guide that moves and directs human behavior, including learning behavior. Motivation in learning contained the desire that activates, distributes, and directs the attitude and behavior of individuals to learn " [3]. Based on that opinions, it can be concluded that the motivation to learn is an encouragement that comes from within a person who can move and direct human behavior including behavior in learning. Self-motivation can encourage students' desire to activate and drive behavior in the learning process.

In addition, the way students learn is one of the factors that allegedly affect the activeness learning of students in the classroom. Dalyono (2012: 57) said that "The way a person learns also affect the achievement of learning outcomes" [2]. According to Slameto (2003: 82) "The way of learning is a method or path that must be taken to achieve the goal in the learning process that is to gain knowledge, attitudes, skills" [17]. Another opinion according to Tu'u in Peterria (2016) stated that "An effective way of learning is to concentrate before and during learning, to quickly re-examine the material already received, read carefully the material being studied and try to master it as well as possible and try to solve and train the questions " [13].

Another factor that is suspected to affect the learning activity is the variation of teaching style. Varied teaching styles can make the students' spirit in following the teaching and learning activities. If teachers in the learning process do not use variations, it will be boring students, students attention tend to decrease, drowsiness, and consequently the goal is not achieved (Djamarah \& Aswan, 2006: 160) [4]. According to Hasibuan \& Moedjiono (2009: 64) "Skills in using variation can be interpreted as the actions of teachers in the context of teaching and learning process that aims to overcome student boredom, enthusiasm, and play an active role" [8]. Partono \& 
Mubarokah (2009) said that "Teachers must have skills in using variations; it means the boredom caused by the presentation of stagnant (classical) learning activities results in the attention, motivation, and interest of students on lessons, teachers, and schools. For that, it needs to be diversity in the presentation of learning activities" [12].

Based on the results of interviews on student activeness learning to the teacher's general administrative subjects on January 20, 2018 explained that the students' learning activities are still low. It can be seen when the teacher gives the opportunity to ask the students still tend to be silent and rarely ask, the students are not confident when answering questions from the teacher, students do not pay attention when the teacher is explaining the material, students who sleepy during the lesson, students who do practice questions by looking at the work of a friend, and the concentration level of the students does not run from the beginning of the lesson until the end of the lesson, for example there are still students who chatted with their friends during the lesson. Therefore, it is difficult for teachers to know the extent to which students' understanding of the material has been taught.

Based on the results of the interviews, it showed that the learning process is still not running effectively because the level of students' active is also low, to strengthen the suspicion the researcher made initial observations using a questionnaire distributed to 30 respondents randomly to three classes X Program Expertise Automation and Governance Offices to find out how the conditions that occur in the field about learning motivation, the way of learning, the variations of teaching styles, and student learning activities.

TABLE 1: Data of Initial Observation Result of Learning Active.

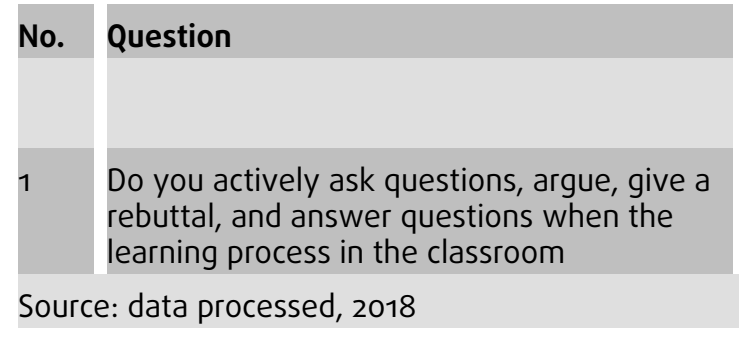

\begin{tabular}{|c|c|c|}
\hline \multicolumn{2}{|c|}{ Students } & Total \\
\hline Active & $\begin{array}{c}\text { Less Active / } \\
\text { passive }\end{array}$ & \\
\hline 11 & 19 & 30 \\
\hline
\end{tabular}

Based on table 1, it can be seen that students who have activeness learning is 36.66percent of 30 students, the rest is 63.33perent of students who are less active/passive in following the learning process. This shows that the students' learning activities are still low. Based on the results of observations and interviews above, it needs follow-up for learning objectives can be achieved optimally. Sadirman (2007: 97) explained that "When follow the learning activities, students must actively do. So 
in learning, it needs activity, without activity, learning process is not possible to run well" [16].

Motivation is one of the factors that allegedly can affect student learning active in class. The higher the motivation to learn the higher the level of student learning activity. Motivation learning is needed in the process of teaching and learning activities, because with a high motivation to learn it will make students active in the learning process and understand the material described by the teacher. The following data obtained through the spreading of the questionnaire to 30 respondents on the initial observation of learning motivation. The result shows that student's learning motivation is high which can be seen in table 2 .

TABLE 2: Data of Initial Observation Result of Learning Active.

\begin{tabular}{l|l|c|}
$\begin{array}{l}\text { No. } \\
1\end{array}$ & Statement & Score \\
\hline 2 & $\begin{array}{l}\text { I am happy to attend General Administration lessons } \\
\text { I always follow the learning process and try to master }\end{array}$ & $90 \%$ \\
\hline 3 & $\begin{array}{l}\text { I accomplish my tasks thoroughly and persistently } \\
\text { I am not easily satisfied with the value that I get even }\end{array}$ & $76,66 \%$ \\
\hline 4 & $\begin{array}{l}\text { l though it is good } \\
\text { I am always looking for other learning resources }\end{array}$ & $64 \%$ \\
\hline 5 & $\begin{array}{l}\text { beside those given by the teacher } \\
\text { I try to read and review the material before I really } \\
\text { understand the material }\end{array}$ & $72 \%$ \\
\hline 6 & $75,11 \%$ \\
\hline
\end{tabular}

Based on table 2, it showed that the percentage of students who have learning motivation is 75.11percent. So it can be concluded based on the data in the table above, the researcher suspect that the students' learning motivation is high. An earlier study conducted by Amalia (2016) in a journal indicates that there is a positive and significant influence between self-efficacy, learning motivation, teaching style, and family environment on student learning activity of economy class XI IPS SMA Negeri 1 Pemalang, the influence of learning motivation on learning activity is 10,05percent [1].

Another factor that allegedly influenced the liveliness of learning is the way of learning. Dalyono (2012: 57) said that "The way a person learns also affect the achievement of learning outcomes" [2]. According to Slameto (2003: 82) "Way of learning is a method or path that must be taken to reach the goal in learning, which is getting knowledge, attitude, and skill" [17]. The better the way of learning then the students active will be higher too. Based on the results of initial questionnaire dissemination to 30 respondents to General Administrative subjects on how students learn, it showed 
that the way students learn can be said well. This can be seen in the data obtained in table 3.

TABLE 3: Initial Observation Data on the Way of Learning.

\begin{tabular}{|c|c|c|}
\hline No. & Statement & Score \\
\hline 1 & I have a learning schedule at home & $80 \%$ \\
\hline 2 & My existing learning schedule has been done well & $79,33 \%$ \\
\hline 3 & $\begin{array}{l}\text { I always take note of the material given by the } \\
\text { teacher }\end{array}$ & $86,66 \%$ \\
\hline 4 & I read the material first before the lesson starts & $64,66 \%$ \\
\hline 5 & I always fill my spare time by reading textbooks & $60,66 \%$ \\
\hline 6 & $\begin{array}{l}\text { I always concentrate and focus on the material } \\
\text { during the learning process }\end{array}$ & $71,33 \%$ \\
\hline \multicolumn{2}{|c|}{ Average score percentage } & $73,77 \%$ \\
\hline \multicolumn{3}{|c|}{ Source: data processed, 2018} \\
\hline
\end{tabular}

Based on table 3, it showed that the percentage of student's way of learning is 73,77percent. So it can be concluded based on the data in the table above, the researcher suspect that the way students learn is good. This is supported by previous research conducted by Nuryati (2016) in a journal whose results indicate that there is a positive and significant influence between the way of learning, learning discipline, and the motivation of activeness learning, with the influence of learning method toward activeness learning (Case study of students class X Administration Expertise Office Program of Training Archives at SMK Negeri 3 Jepara) amounted to 48.16percent [11]. From the results of these studies, it can be concluded that the way students learn can improve student activeness learning in following the learning process.

In addition to the motivation and the way of learning, other factors that allegedly affect the activity of student learning is a variety of teaching styles. The better the variation of teaching styles will be the better the level of student activeness learning. According to Kardoyo \& Hayuningtyas (2009) "Teachers as teachers or educators, teachers are one of the critical success factors. That is why every innovation of education, especially in the curriculum and improvement of human resources which is resulted from education efforts always boils down to the teacher factor. This shows how the existence of the role of teachers in education " [9]. Here are the results obtained from the initial questionnaire to 30 respondents regarding the variety of teaching styles. The results obtained that the variation of teaching styles is good which can be seen in table 4 .

Based on table 4, it shows that the percentage of teacher's teaching style variation is 83.11percent. So it can be concluded based on the data in the table above, 
TABLE 4: Initial Observation Data on Variation of Teaching Style.

\begin{tabular}{l|l|c|}
\hline No. & Statement & Score \\
\hline 1 & $\begin{array}{l}\text { The teacher's voice was heard clearly when } \\
\text { explaining the material }\end{array}$ & $82,66 \%$ \\
\hline 2 & $\begin{array}{l}\text { Teachers can attract students' attention by way } \\
\text { of delivering the taught material }\end{array}$ & $85,33 \%$ \\
\hline 3 & $\begin{array}{l}\text { Teachers can create interactive classes for } \\
\text { students to be active }\end{array}$ & $81,33 \%$ \\
\hline 4 & $\begin{array}{l}\text { The teacher admonishes the students when } \\
\text { there are students who speak for themselves } \\
\text { when they are taught }\end{array}$ & $84,66 \%$ \\
\hline 5 & $\begin{array}{l}\text { The teacher is silent for a moment when there } \\
\text { are students who make a noise in class }\end{array}$ & $78,66 \%$ \\
\hline 6 & $\begin{array}{l}\text { The teacher not only explain the material by } \\
\text { talking alone but he combine with the motion of } \\
\text { the hands, feet, and head as a props to clarify } \\
\text { the material delivered }\end{array}$ & $86 \%$ \\
\hline Average score percentage & \\
\hline Source: data processed, 2018 & $83,11 \%$ \\
\hline
\end{tabular}

the researchers suspect that the variation of teaching styles is good. In the process of teaching and learning activities, teachers should use a variety of good teaching styles to enhance students' learning activities. This is supported by previous research conducted by Susilowati (2016) shows that "Partially there is a positive and significant influence between the variations of teaching styles to the learner of students class XI of Administrative Office Department on the subject of applying software applications in SMK Muhammadyah Bobotsari is 7, 08percent [20].

Based on the background that has been described above, then the formulation of the problem in this research is whether there is a simultaneously and partially influence of learning motivation, the way of learning, and variation of teaching style to the learning activity on general administration subjects of students class X Expertise Automation Program and Office Governance at SMK NU 01 Kendal Academic Year 2017/2018?. The purpose of this research is to know simultaneously and partially the influence of learning motivation, the way of learning, and variation of teaching style to activeness learning in general administration subjects of students class $X$ Automation Expertise Program and Office Management at SMK NU 01 Kendal Academic Year 2017/2018.

\section{Methods of the Study}

Type and design of this research is quantitative causality research. Sugiyono (2017: 14) stated that "Quantitative research methods can be interpreted as research methods 
based on positivism philosophy, used to examine a particular population or sample, sampling techniques are generally done randomly, collection of the data used research instruments, data analysis is quantitative/ statistics in order to test the hypothesis set" [19]. The population in this study is the students' class X of Automation Expertise Program and Office Management SMK NU 01 Kendal Academic Year 2017/2018 which amounts to 80 students. The sampling technique in this research is done by using saturated sampling. According to Sugiyono (2017: 124) "Saturation sample is a technique of determining the sample when all members of the population used as a sample" [19].

This research consists of two variables: free variables and dependent variables. The independent variables in this research are: Learning Motivation $\left(X_{1}\right)$, Learning Method ( $\left.X_{2}\right)$, and Variation of Teaching Style $\left(X_{3}\right)$. And the dependent variable in this research is the Activeness of Student Learning $(Y)$. Data collection methods used in this study is observations, interviews, questionnaires, and documentation. While the data analysis method used is multiple regression analysis, hypothesis test analysis consisting of simultaneous test ( $F$ test), partial test ( $t$ test) simultaneous coefficient of determination, partial determination coefficient, and descriptive analysis percentage.

The classical assumption test in the study consisted of normality test, linearity test, multicollinearity test, and heteroscedasticity test. Normality test in this research used statistic test Kolmogorov-Smirnov Test (KS), it showed that Kolmogorov-Smirnov Test (KS) with SPSS For Windows Release 23, the result of normality test showed that Kolmogorov-Smirnov Test (KS of 0.091 with Asymp. Sig. (2-tailed) is 0.484 . Since the value of Asymp Sig. (2-tailed) is greater than 0.05 it indicates that the regression model satisfies the assumption of normality which means that the residual data is normally distributed. The linearity test of learning motivation that the value of $F$ equal is 86.829 with the significance value $0.000<0.05$ which means that there is a linear correlation between learning motivation variable $\left(X_{1}\right)$ to activeness learning $(Y)$.The result of linearity test showed that $F$ value equal to 51.561 with significance value 0.000 $<0.05$ which means that there is a linear relationship between learning method variable $\left(X_{2}\right)$ to activeness learning $(Y)$. The result of linearity test of teaching style variation showed that the value of $F$ is 15.2247 with the significance value $0.000<0.05$ which means that there is a linear relationship between the variation of teaching style $\left(X_{3}\right)$ to the activeness learning $(Y)$. The calculation of multicolinearity test in this research used SPSS For Windows Release 23. Multicollinearity test result showed that learning motivation $\left(\mathrm{X}_{1}\right)$, learning method $\left(\mathrm{X}_{2}\right)$, and teaching style variation $\left(\mathrm{X}_{3}\right)$ have tolerance value $\geq 0.10$ that is learning motivation 0.417 ; way of learning is 0.462 ; and 
variation of teaching style is 0.860 . As for the VIF value indicateed that all variables have a VIF value $\leq 10$ that is learning motivation 2.398; how to learn is 2.164; and teaching style variation is 1,163 . So it can be concluded that there is no multicollinearity between independent variables in the regression model. Heteroscedasticity test aims to test whether the regression model of variance inequality occurs from one observation residual to another. Heteroscedasticity test in this study using glejser test that if the value of significance is more than 0.05 then the variable does not occur heteroscedasticity. The result of heteroscedasticity test obtained by glejser test showed that learning motivation variable $\left(X_{1}\right)$ is 0.651 ; way of learning $\left(X_{2}\right)$ is 0.878 ; and teaching style variation $\left(X_{3}\right)$ is 0.724 . All the independent variables in this study had significance more than 0.05 . This shows that the regression model do not occur heteroscedasticity.

TABLE 5: Results of Multiple Regression Analysis.

\begin{tabular}{|c|c|c|c|c|c|c|}
\hline \multicolumn{7}{|c|}{ Coefficients $^{a}$} \\
\hline \multicolumn{2}{|c|}{ Model } & \multicolumn{2}{|c|}{ Unstandardized Coefficients } & \multirow{2}{*}{$\begin{array}{c}\text { Standardized } \\
\text { Coefficients } \\
\text { Beta }\end{array}$} & \multirow[t]{2}{*}{$\mathrm{t}$} & \multirow[t]{2}{*}{ Sig. } \\
\hline & & B & Std. Error & & & \\
\hline \multirow[t]{4}{*}{1} & (Constant) & 3.304 & 5.917 & & .558 & .578 \\
\hline & $\begin{array}{l}\text { Learning } \\
\text { Motivation }\end{array}$ & .406 & .104 & .452 & 3.919 & .000 \\
\hline & Way of Learning & .221 & .090 & .268 & 2.444 & .017 \\
\hline & $\begin{array}{l}\text { Teaching Style } \\
\text { Variation }\end{array}$ & .170 & .068 & .201 & 2.496 & .015 \\
\hline \multicolumn{7}{|c|}{ a. Dependent Variable: Activeness Learning } \\
\hline \multicolumn{7}{|c|}{ Source: data processed, 2018} \\
\hline
\end{tabular}

Based on the result of multiple regression analysis above showed that the regression equation that is: $Y=3.304+0.406 X_{1}+0.221 X_{2}+0.70 X_{3}+$ e. The regression equation can be interpreted that if the independent variables are learning motivation, way of learning, and variation of teaching style is o (zero), the dependent variable that is activeness learning is positive 3.304. If $X_{1}$, learning motivation, experienced $1 \%$ satisfaction and other independent variables are fixed, the dependent variable that is activeness learning will increase by 0.406 . If $X_{2}$, the way of learning, experienced $1 \%$ satisfaction and other independent variables are fixed, the dependent variable that is activeness learning will increase by 0.221 . If $X_{3}$, the variation of teaching style, has increased by 1percent and other independent variables are fixed, the dependent variable that is activeness learning will experience an increase of 0.170 .

Based on the hypothesis test on simultaneous test ( $F$ test) it is obtained that $F_{\text {count }}$ is 34.638 with a significance value of 0.000 . This means that the level of significance in 
TABle 6: Simultaneous Test Results (Uji F).

\begin{tabular}{|c|c|c|c|c|c|c|}
\hline \multicolumn{7}{|c|}{ ANOVAa } \\
\hline \multicolumn{2}{|c|}{ Model } & Sum of & Df & Mean & $\mathrm{F}$ & Sig. \\
\hline \multirow[t]{3}{*}{1} & Regression & 1664.853 & 3 & 554.951 & 34.638 & $.000^{b}$ \\
\hline & Residual & 1217.634 & 76 & 16.022 & & \\
\hline & Total & 2882.487 & 79 & & & \\
\hline \multicolumn{7}{|c|}{ a. Dependent Variable: Activeness Learning } \\
\hline \multicolumn{7}{|c|}{$\begin{array}{l}\text { b. Predictors: (Constant), Variation of Teaching Style, Way of Learning, Learning } \\
\text { Motivation }\end{array}$} \\
\hline \multicolumn{7}{|c|}{ Source: data processed, 2018} \\
\hline
\end{tabular}

the test $F<0.05$ which means $F_{\text {count }}$ is significant. The results of this analysis can be concluded that Ha1 in this study which reads "There is a simultaneous influence between learning motivation, way of learning, and variation of teaching styles to activeness learning on general administration subjects of students class $X$ Automation Expertise Program and Office Management at SMK NU 01 Kendal Academic Year 2017/2018 ", accepted.

TABle 7: Partial Test Results (Uji t).

\begin{tabular}{l|l|c|c|c|c|}
\hline \multicolumn{5}{|c|}{ Coefficients $^{a}$} \\
Model & Unstandardized Coefficients & $\begin{array}{c}\text { Standardized } \\
\text { Coefficients }\end{array}$ & T & Sig. \\
\hline 1 & B & Std. Error & Beta & \\
\hline $\begin{array}{l}\text { (Constant) } \\
\text { Learning } \\
\text { Motivation }\end{array}$ & 3.304 & 5.917 & & .558 & .578 \\
\hline $\begin{array}{l}\text { Way of } \\
\text { Learning }\end{array}$ & .406 & .104 & .452 & 3.919 & .000 \\
\hline $\begin{array}{l}\text { Teaching } \\
\text { Styles } \\
\text { Variation }\end{array}$ & .221 & .090 & .268 & 2.444 & .017 \\
\hline $\begin{array}{l}\text { a. Dependent Variable: Activeness Learning } \\
\text { Source: data processed, } 2018\end{array}$ & .068 & .201 & 2.496 & .015 \\
\hline
\end{tabular}

Based on the hypothesis test on partial test (t test) for learning motivation variable $\left(\mathrm{X}_{1}\right)$ it is obtained that $\mathrm{t}_{\text {count }}=3.919$ with significance $0.000<0.05$. These results indicate that $t_{\text {count }}$ is significant, hence the hypothesis on Haz which reads "There is partial influence between learning motivation to activeness learning in general administration subjects of students class X Automation Expertise Program and Office Management at SMK NU 01 Kendal Academic Year 2017/2018", be accepted. Partial test result for learning method variable $\left(X_{2}\right)$ is obtained $t_{\text {count }}=2.444$ with significance $0.017<0.05$. These results indicate that $t_{\text {count }}$ is significant, then the hypothesis on Haz which reads 
"There is a partial influence between the way of learning to activeness learning in general administration subjects of students class X Automation Expertise Program and Office Management at SMK NU 01 Kendal Academic Year 2017/2018", be accepted. Partial test results for teaching style variation variables $\left(X_{3}\right)$ is obtained $t_{\text {count }}=2.496$ with a significance of $0.015<0.05$. These results indicate that $t_{\text {count }}$ is significant, hence the hypothesis on $\mathrm{Ha} 4$ which reads "There is partial influence between the variation of teaching styles on the activeness learning on general administration subjects of students class X Automation Expertise Program and Office Management at SMK NU 01 Kendal Academic Year 2017/2018 ", be accepted.

TABLE 8: Calculation Results of Simultaneous DeterminationCoefficient $\left(R^{2}\right)$.

\begin{tabular}{|c|c|c|c|c|}
\hline \multicolumn{5}{|c|}{ Model Summary } \\
\hline Model & $\mathrm{R}$ & R Square & $\begin{array}{l}\text { Adjusted R } \\
\text { Square }\end{array}$ & $\begin{array}{l}\text { Std. Error of the } \\
\text { Estimate }\end{array}$ \\
\hline 1 & $.760^{a}$ & .578 & .561 & 4.003 \\
\hline \multicolumn{5}{|c|}{$\begin{array}{l}\text { a. Predictors: (Constant), Teaching Style Variation, Way of Learning, Learning } \\
\text { Motivation }\end{array}$} \\
\hline \multicolumn{5}{|c|}{ Source: data processed, 2018} \\
\hline
\end{tabular}

Based on the result of simultaneous determination coefficient $\left(R_{2}\right)$ it is obtained that Adjusted $R$ Square value is 0.561 . Adjusted $R$ Square value multiplied 10opercent to know the magnitude of $R_{2}$ that is equal to 56.1percent. These results indicate that the magnitude of the influence of learning motivation, way of learning, and teaching styles variation on activeness learning in general administration subjects $X$ class students Automation Expertise Program and Office Management at SMK NU 01 Kendal academic year $2017 / 2018$ is 56.1 percent and the rest of 43.9 percent is influenced by other variables that is not examined in this study.

Meanwhile, to know the percentage of partial independent variable to the dependent variable can be known from the coefficient of partial determination on the partial column. The amount of partial value on learning motivation variable $\left(X_{1}\right)$ is $=0.410$, so the influence of learning motivation variable to activeness learning is (0.410) 2 x10opercent $=16.81$ percent. The amount of partial value on way of learning variable $\left(X_{2}\right)$ is $=0.270$, so the influence of learning motivation variable to activeness learning is (0.270) 2 x10opercent $=7.29$ percent. The amount of partial value on teaching style variation variables $\left(X_{3}\right)$ is $=0.275$, so the influence of teaching style variation variable to activeness learning is ( 0.275$) 2$ x10opercent $=7.56$ percent .

Based on the results of descriptive analysis, the percentage of learning motivation variable indicates that the learning motivation has an index value of 71.26 percent, it is in the high criterion with 5 (five) indicators that are doing the task diligently, 
TABLE 9: Calculation Result of Partial Determination Coefficient $\left(r^{2}\right)$.

\begin{tabular}{|c|c|c|c|c|c|c|c|c|c|}
\hline \multicolumn{10}{|c|}{ Coefficients $^{a}$} \\
\hline & \multirow[t]{2}{*}{ Model } & \multicolumn{2}{|c|}{ Unstandardized Coefficients } & \multirow{2}{*}{$\begin{array}{c}\text { Standardized } \\
\text { Coefficients } \\
\text { Beta }\end{array}$} & \multirow[t]{2}{*}{ T } & \multirow[t]{2}{*}{ Sig. } & \multicolumn{3}{|c|}{ Correlations } \\
\hline & & B & Std. Error & & & & $\begin{array}{l}\text { Zero- } \\
\text { order }\end{array}$ & Partial & Part \\
\hline \multirow[t]{4}{*}{1} & (Constant) & 3.304 & 5.917 & & .558 & .578 & & & \\
\hline & $\begin{array}{l}\text { Learning } \\
\text { Motivation }\end{array}$ & .406 & .104 & .452 & 3.919 & .000 & .719 & .410 & .292 \\
\hline & $\begin{array}{l}\text { Way of } \\
\text { Learning }\end{array}$ & .221 & .090 & .268 & 2.444 & .017 & .634 & .270 & .182 \\
\hline & $\begin{array}{l}\text { Teaching } \\
\text { Styles } \\
\text { Variation }\end{array}$ & .170 & .068 & .201 & 2.496 & .015 & .410 & .275 & .186 \\
\hline \multicolumn{10}{|c|}{ a. Dependent Variable: Activeness Learning } \\
\hline \multicolumn{10}{|c|}{ Source: data processed, 2018} \\
\hline
\end{tabular}

facing difficulties resiliently, quickly bored on routine tasks, maintaining opinions, and finding and solving problems. The index value for the facing the task indicator is at high criteria with the index value of 76.81percent. Indicator of facing difficulties resiliently in moderate criteria with an index score of 68.17 percent. Indicator of quickly bored on routine tasks in moderate criteria with an index score of 67.83 percent. Maintaining opinions indicator is in high criteria with index score of 73.83 percent. Finding and solving problems indicator is in medium criteria with index score of 69.67percent.

Descriptive analysis results on variable percentage of way of learning indicates that way of learning have index value equal to 67.18percent it is in medium criterion with 5 (five) indicator that is making schedule and its implementation, reading and making note, repeating lesson material, concentration, and doing task. Index value for making schedule and its implementation indicator is in medium criterion with index value equal to 68.31percent. Reading and making note indicator is in medium criterion with index value equal to 64.88percent. Repeating lesson material indicator is in medium criterion with index value equal to 62.75 percent. Concentration indicator is in medium criterion with index value equal to 68.5percent. Doing tasks indicator is in high criteria with an index score of 71.5 percent.

Descriptive analysis result of teaching styles variation variable shows that the variation of teaching style has an index value of 83.99percent it is in high criterion with 6 (six) indicators: variation of voice, concentration of attention, silence, sight contact, body movement and mimic, teacher position. Index value for sound variation indicator is in high criterion with index value equal to 87.5percent. Indicator of concentration is in high criteria with an index value of 82.38 percent. The silence indicator with an index 
value is 86.75percent. Sight contact indicator is in high criterion with index value equal to 84.58percent. Body movement and mimic indicator is in high criterion with index value equal to 81.33percent. Indicator of teacher position is in high criterion with index value equal to 81.17percent.

Study about the influence of learning motivation, way of learning, and teaching styles variation on activeness learning, the results of the research indicate that there is a positive and significant influence between learning motivation, way of learning, and teaching styles variation on activeness learning. Based on $\mathrm{F}$ test, the significance value is $0.000<0.05$ which means that Ha1 is accepted. This result indicates that the learning motivation, the way of learning, and the teaching styles variation simultaneously influences the activeness learning in the general administration subjects of the students class X Expertise of Automation Program and Governance of Schools of the Year 2017/2018. It shows that the higher the motivation to learn, the way of learning, and the teaching style variation, the higher the level of student activeness learning. Similarly, the lower the motivation to learn, the way of learning, and the teaching styles variation will reduce the level of student activeness learning.

The coefficient result of simultaneous determination showed that 56.1percent student's activeness learning variable can be explained by the independent variable that is learning motivation, way of learning, and variation of teaching style. While the rest of 43.9percent influenced by other variables that is not examined in this study. Based on the results the data was obtained by the regression equation is $Y=3.304+0.406 X_{1}$ $+0.221 X_{2}+0.170 X_{3}+$ e. This equation can be interpreted that if the independent variables are learning motivation, way of learning, and variation of teaching style is 0 (zero), the dependent variable, activeness learning, is 3.304. If $X_{1}$ is learning motivation experienced an increase of 1percent and other independent variables are fixed, the dependent variable that is activeness learning will increase by 0.406 . If $X_{2}$ is the way of learning experienced an increase by 1 percent and other independent variables are fixed, the dependent variable that is activeness learning will increase by 0.221 . If $X_{3}$ is the teaching styles variation has increased by 1 percent and other independent variables are fixed, the dependent variable that is learning activeness will experience an increase of 0.170 .

The influence of learning motivation on activeness learning, based on calculation result using SPSS For Windows Release 23 showed that partial hypothesis test result ( $t$ test) has $t_{\text {count }}$ of 3.919 with significance 0.000 . This means that the significance value of learning motivation $\left(X_{1}\right)$ is less than 0.05 , so it can be concluded that the hypothesis Haz which states that there is influence of learning motivation to activeness learning 
in general administration subject students' class X Program Expertise Automation and Office Governance at SMK NU 01 Kendal Academic Year 2017/2018 accepted. Learning motivation variable $\left(\mathrm{X}_{1}\right)$ has a positive influence on the activeness learning; it can be seen on the result of regression equation showing that the regression coefficient is 0.406 . This can be interpreted if the learning motivation variable $\left(X_{1}\right)$ has increased by 1percent while other variables remain, the activeness learning or dependent variable will increase by 0.406 . Therefore, it can be seen that the higher the motivation to learn the higher the level of student activeness learning. The results of this study indicate that the motivation to learn has an influence on the activeness learning in general administrative subjectsof students class $X$ Automation Expertise Program and Office Governance at SMK NU 01 Kendal Academic Year 2017/2018.

Based on the results of descriptive analysis the percentage of learning motivation variable of the respondents as many as 80 students with 18 statements, indicating that the students' learning motivation is in high criteria, it can be seen from the value of the index of learning motivation variable of 70.76percent. This is shown from the indicatorof facing the task diligently is in high criteria with an index value of 74.31percent. Indicator of facing high tasks such as always follow general administrative lessons and try to master the material, read and re-learn the material before understanding the material, complete the task continuously, thoroughly and diligently and do the task well and submit on time. Indicator of facing difficulties resiliently is in moderate criteria with an index score of 68.17percent. This shows that the motivation in facing difficulties resiliently is good enough as not easily satisfied with the score that has been obtained, do the problems themselves without the help of others, and solve difficulties by doing the exercises. Indicator of quickly bored on routine tasks in moderate criteria with an index score of 67.83 percent.This shows that the motivation in routine tasks are quite good such as finding other learning resources, re-learning the material that has been taught, and interested in the questions given by the teacher. Indicator of maintaining opinions in high criteria with index score of 73.83percent. This shows the motivation in maintaining his opinion is already high as not affected by the answers of friends who are different from the his answers, have a reason to defend opinions, and confident with the ability possessed. Indicator of happy to find and solve problems is in medium criteria with index score of 69.67percent. This shows the motivation in the pleasure to find and solve the problem is good enough as doing the exercises, looking for other learning resources, and trying to do the exercises despite difficulties.

The results of this study is in accordance with the opinion of Sadirman (2007: 75) explained that the motivation can be interpreted as the overall driving force within 
the students that lead to learning activities, which ensures the continuity of learning activities and provide direction on learning activities, so that the desired goal by the subjects it can be achieved [16]. The results of this study is strengthened by a research conducted by Amalia (2016) entitled "The Effect of Self Efficacy, Learning Motivation, Teachers Teaching Style, and Family Environment Towards Student Activeness Learning of Economy Subject in Class XI IPS SMA Negeri 1 Pemalang" which stated that there is positive and significant influence on learning motivation to student activeness learning of economy subject class XI IPS SMA Negeri 1 Pemalang is equal to 10.05percent [1].

The influence of learning method toward activeness learning, based on calculation result using SPSS For Windows Release 23 showed that the result of partial hypothesis test ( $t$ test) has a $t_{\text {count }}$ value of 2.444 with significance 0.017 . This means that the significance of the way of learning $\left(X_{2}\right)$ is less than 0.05 , so it can be concluded that the hypothesis Haz which states that there is influence of learning method toward the activeness learning on general administration subjects students class X Automation Expertise Program and Office Management in SMK NU 01 Kendal Academic Year 2017/2018 accepted. Learning method variable (X2) has a positive effect on the activeness learning, it can be seen in the regression equation which shows that the magnitude of the regression coefficient is 0.221 . This can be interpreted if the learning method variable $\left(X_{2}\right)$ has increased by $1 \%$ while other variables remain, the activeness learning or dependent variable will increase by 0.221 . Therefore, it can be seen that the better the learning method then the student activeness learning will be better. The results of this study indicate that the way of learning has an influence on the activeness learning in the general administration subjects of students' class X Automation Expertise Program and Office Governance at SMK NU 01 Kendal Academic Year 2017/2018.

Based on the results of descriptive analysis, the percentage of learningmethod from the respondent as many as 80 students with 17 statements, indicating that the way of student learning is good enough that can be seen from the value of the way of learning variable index of 67.18percent. Indicator of making schedule and its implementation is in medium criterion with the index value equal to 68.31percent. This shows the way of learning in making the schedule and the implementation is good enough such as having a learning schedule, carrying out a good study schedule, having a special place to learn, and having tutor teachers. Indicator of reading and making note is in medium criterion with index value equal to 64.8percent. This indicates that the way of learning in which reading and making note is good enough such as noting down the material given by the teacher, reading the material first before the lesson begins, writing down 
the lesson before it begins, and filling the spare time by reading the book of public administration. Indicator of repeating the lesson material is in medium criterion with index value equal to 62.75percent. This shows that the way of learning in repeating the lesson is good enough, such as re-learning the material, doing the exercises that have been modified, and reworking the home exercises that have been done in school. Indicator of concentration is in medium criterion with index value equal to 68.5percent. This shows the way of learning in concentration is good enough such as understanding the material that has been taught by the teacher and paid close attention from the beginning to the end of the lesson. Indicator of doing tasks is in high criteria with an index score of 71.5percent. This shows the way of learning in doing the task is good such as always submitting the tasks on time, doing homework, and always doing the exercises given by teachers.

The results of this study is in accordance with the opinion of Slameto (2003: 82) explained that the way of learning is a method or path that must be taken to achieve the goals in learning, which is getting knowledge, attitude, and skills [17]. The results of this study is strengthened by a research conducted by Nuryati (2016) with the title "The Influence of Learning Methods, Discipline, and Motivation of Student Activeness Learning (Case Study of Student Class X Administration Skill Program Office of Archival Training Archives at SMK Negeri 3 Jepara Academic Year 2014 / 2015)" which stated that there is a positive and significant influence on the way of learning toward student activeness learning (Case Study of Student Class X Administration Expertise Office Program of Training Archives at SMK Negeri 3 Jepara Academic Year 2014/2015) equal to 48.16 percent [11].

The influence of teaching style variation on activeness learning, based on calculation result using SPSS For Windows Release 23 showed that partial hypothesis test result (t test) has a $t_{\text {count }}$ of 2.496 with significance 0.015 . This means that the significance value of teaching style variation $\left(X_{3}\right)$ is smaller than 0.05 , so it can be concluded that the hypothesis $\mathrm{Ha} 4$ which stated that there is influence of teaching styles variation toward activeness learning in general administration subjects of students class $X$ of Expertise Automation Program and Office Governance at SMK NU 01 Kendal Academic Year $2017 / 2018$ accepted. The variation of teaching style $\left(X_{3}\right)$ has a positive influence on the activeness learning, it can be seen in the regression equation which showed that the magnitude of the regression coefficient is 0.170 . This can be interpreted if the variation of teaching style $\left(X_{3}\right)$ has increased by 1percent while the other variable remains, the activeness learning or dependent variable will increase by 0.170 . Therefore, it can be seen that the better the motivation to learn the student activeness learning will 
be higher. The results of this study indicate that the variation of teaching style has an influence on the learning activity on general administration subjects of students class X of Automation Expertise Program and Office Governance at SMK NU 01 Kendal Academic Year 2017/2018.

Based on the results of descriptive analysis, the percentage of teaching styles variation variable from 80 respondents with 20 statements, indicating that the variation of teaching style is good, it can be seen from index variation of teaching style variation of 83.99percent. Voice variation indicator is in high criteria with index score of 87.5percent. This suggested that the variation of teaching styles is as good as the voice of the teacher is audible when explaining the material, the teacher uses intonation clearly, and the teacher puts the material in clear and understandable language. Indicator of concentration is in high criteria with an index value of 82.38percent. This suggested that the variation of teaching styles in concentration is as good as the teacher attracts and focuses the students before the lesson begins, the teacher draws the attention of the students by the way of deliver the material, the teacher is able to calm the rowdy students, and the teacher can create interactive classes. Indicator of silence is in high criterion with index value equal to 86.75percent. This showed the variation of teaching styles in making silence as good as teachers reprimand students when students speak for themselves during the lesson, the teacher is silent for a moment when there are noisy students, the teacher pauses for a while as it will continue the material, and the teacher pauses as students making note. Sight contact indicator is in high criterion with index value equal to 84.58 percent.This shows that the variation of the teaching style in making a contact is already good as the teacher looks at all the students while explaining the material, the teacher looks at the questioning student, and the teacher looks at the noisy students. Body movement and mimic indicator is in high criterion with index value equal to 81.33percent. This shows the variation in body movement and mimic is good as the teacher explains the material not only by speaking but combining with the limbs, and the teacher tapping the hand to the table or whiteboard when there are noisy students. Indicator of teacher position change is in high criterion with index value equal to 81.17percent. This shows the variety of teaching styles in the teacher's changing position as well as the teacher walking around looking at the students while explaining the material, the teacher does not just sit down while explaining the material, and the teacher does a sudden jump when he sees the student crowd.

The results of this study is in accordance with the opinion of Hasibuan \& Moedjiono (2009: 64) stated that variation is interpreted as a teacher's action in the context of 
teaching and learning process that aims to overcome the boredom of students, so that in the learning process students always show diligence, enthusiasm, and play an active role [8]. The results of this study is reinforced by a research conducted by Susilowati (2016) with the title "The Influence of Learning Motivation, Class Management Skills, and Variation Teaching Style Toward Student Activeness Learning of Class XI of Administrative Office Department On The Subject Of Operating Software Applications In SMK Muhammadiyah Bobotsari At Academic Year 2015/2016" which stated that there is a positive and significant influence of teaching styles variation toward the activeness learning of students class XI Office Administration Department In Subjects Operating Software Applications at SMK Muhammadiyah Bobotsari Year Teaching 2015/2016 equal to 7.08 percent.

\section{Conclusion and Suggestion}

Based on the results and discussion in this research, it can be concluded as follows: 1) There is the influence of learning motivation, learning method, and variation of teaching style toward activeness learning in general administration subjects of students class X Automation Expertise Program and Office Governance Skills at SMK NU $01 \mathrm{Kendal}$ at academic year 2017/2018 equal to 56.1percent; 2) There is an influence of learning motivation on activeness learning equal to 16.81percent; 3 ) There is an influence of learning method on activeness learning equal to 7.29percent; 4) There is influence of variation of teaching style toward activeness learning 7.56percent.

Based on the results of the research and discussion described above, the researcher gives the following suggestions: 1) Regarding to the learning motivation, the lowest index value per item is found in the tenacious indicator of facing difficulties that is in the statement that the student keep trying to do his own questions without help from others. Suggestions that can be given are teachers should supervise the students while doing the exercise and give awards to the students when students get the highest score in doing the exercises without the help of others so that the students feel that the effort is not in vain and get appreciation from the teacher; 2) Related to the way of learning, can be given that the parents or family should remind students to study at home, with the supervision of the students in learning; 3 ) In relation to the variation of teaching styles, that can be given are teachers should be silent for a moment when students are busy, reprimand the busy students directly, and look at the crowded students. 


\section{References}

[1] Amalia, K. (2016). Pengaruh Efikasi Diri, Motivasi Belajar, Gaya Mengajar Guru, dan Lingkungan Keluarga Terhadap Keaktifan Belajar Siswa Mata Pelajaran Ekonomi Kelas Xi Ips Sma Negeri 1 Pemalang. Economic Education Analysis Journal, 5(1), 1-12.

[2] Dalyono, M. (2012). Psikologi Pendidikan. Jakarta: Rineka Cipta.

[3] Dimyati, \& Mudjiono. (2006). Belajar dan Pembelajaran. Jakarta: Rineka Cipta.

[4] Djamarah, S., \& Aswan, Z. (2006). Strategi Belajar Mengajar. Jakarta: Rineka Cipta.

[5] Febrianto, A. (2014). Pengaruh Keterampilan Mengelola Kelas dan Gaya Mengajar Guru Terhadap Keaktifan Belajar Siswa Kelas Xi Materi Pembelajaran Pembangunan Ekonomi Sma Negeri 2 Slawi. Economic Education Analysis Journal, 2(3), 1-8.

[6] Ghozali, I. (2016). Aplikasi Analisis Multivariete dengan Program IBM SPSS 23. Semarang: Badan Penerbit Universitas Diponegoro.

[7] Hamalik, 0. (2003). Proses Belajar Mengajar. Jakarta: PT Bumi AksaraHasibuan, J.J., \& Moedjiono. (2009). Proses Belajar Mengajar. Bandung: PT Remaja Rosdakarya.

[8] Hasibuan, J.J., \& Moedjiono. (2009). Proses Belajar Mengajar. Bandung: PT Remaja Rosdakarya.

[9] Kardoyo, -., \& Hayuningtyas, E. (2009). Model Pembelajaran Role Playing Pada Mata Pelajaran Ps-Ekonomi Materi Pokok Manusia Sebagai Makhluk Sosial Dan Ekonomi. Dinamika Pendidikan, 4(2), 141-160.

[10] Majid, A. (2013). Strategi Pembelajaran. Bandung: PT Remaja Rosdakarya.

[11] Nuryati. (2016). Pengaruh Cara Belajar, Disiplin, Dan Motivasi Terhadap Keaktifan Belajar Siswa. Economic Education Analysis Journal, 5(2), 630-642.

[12] Partono. (2009). Persepsi Siswa Atas Pengaruh Keterampilan Mengajar Guru dan Pengelolaan Kelas Terhadap Prestasi Belajar Siswa. Dinamika Pendidikan, 4(1).

[13] Peterria, V. (2016). Pengaruh Lingkungan Sekolah, Cara Belajar, Dan Motivasi Belajar Terhadap Hasil Belajar Siswa Pada Mata Pelajaran Mengelola Peralatan. Economic Education Analysis Journal,5(3), 860-873.

[14] Ratnawati,A. (2014). Pengaruh Kesiapan Belajar, Minat Belajar, Motivasi Belajar, dan Sikap Siswa Terhadap Keaktifan Belajar Siswa Jurusan Administrasi Perkantoran Pada Mata Diklat Produktif Ap Di Smk Negeri 2 Semarang. Economic Education Analysis Journal, 3(1), 77-82.

[15] Rifa'i, A., \& Catharina, T. A. (2012). Psikologi Pendidikan. Semarang: Unnes Press.

[16] Sadirman. (2007). Interaksi dan Motivasi Belajar Mengajar. Jakarta: PT Raja Grafindo Persada. 
[17] Slameto. (2003). Belajar dan Faktor-faktor yang Mempengaruhinya. Jakarta: Rineka Cipta.

[18] Sudjana, H. N. (2010). Cara Belajar Siswa Aktif dalam Proses Belajar Mengajar. Bandung: Sinar Baru Algensindo.

[19] Sugiyono. (2017). Metode Penelitian Pendidikan (Pendekatan Kuantitatif, Kualitatif, dan R\&D). Bandung: Alfabeta.

[20] Susilowati. (2016). Pengaruh Motivasi Belajar, Keterampilan Mengelola Kelas, dan Variasi Gaya Mengajar Terhadap Keaktifan Belajar Siswa Kelas XI Jurusan Administrasi Perkantoran Pada Mata Pelajaran Mengoperasikan Aplikasi Perangkat Lunak Di Smk Muhammadiyah Bobotsari Tahun Ajaran 2015/2016. Economic Education Analysis Journal, 3(1), 1-14.

[21] Tusyanah, Maftukhah, I., Arief, S., \& Sakitri, W. (2016). The Contribution of Classical Music Given Outdoor to Improve Indonesian High School Students Ability in Descritive Text Writing. The Asian EFL Journal, (95), 34-62.

[22] Undang-Undang Republik Indonesia Nomor 20 Tahun 2003 Tentang Sistem Pendidikan Nasional.

[23] Usman, M. U. (2009). Menjadi Guru Profesional. Bandung: PT Remaja Rosdakarya.

[24] Widiati, E. D. N. (2016). Pengaruh Kemampuan Berpikir Kritis, Fasilitas Belajar, dan Gaya Mengajar Terhadap Keaktifan Belajar Siswa Kelas X Pada Mata Pelajaran Ekonomi Di Sma N 2 Kendal. Economic Education Analysis Journal, 3(1), 1-10.

[25] Yulianto, A. (2007). Peningkatan Kualitas Proses Dan Hasil Belajar Mata Kuliah Teori Akuntansi Melalui Pendekatan Discovey Learning. Dinamika Pendidikan, 2(1), 71-84. 